\title{
STUDENTS' ABILITY IN WRITING HORTATORY EXPOSITION OF ELEVENTH GRADE STUDENTS AT SMAN 14 PEKANBARU
}

\author{
Sri Wahyuni \\ Universitas Islam Riau \\ email:wahyuni@edu.uir.ac.id
}

\begin{abstract}
This research represents the descriptive research to describe students' ability of eleventh grade students at SMAN 14 Pekanbaru in writing hortatory exposition text. The total number of eleventh grade students at SMAN 14 Pekanbaru in academic year 2015/2016 was 210 students that consisted of 7 classes. In this research, the researcher used 'cluster random sampling technique" to choose the sample, and the total sample of this research amount to 30 students. The data was collected through writing test, where the students were asked to write a hortatory exposition text based on the topics that were provided by researcher of this research. The test was done around 90 minutes for every time of the test. The students' entire test was scored by two persons as scorers of this research. Those two scores gave scores to the students' test based on the criteria in the instrumentation of this research. The result showed that the student' ability in writing hortatory exposition text was categorized "average to good". It can be proven by the average of students' writing test score that was 61.65 that cannot achieve the passing grade yet.
\end{abstract}

Key words: Writing Ability, Hortatory Exposition Text

\section{KEMAMPUAN SISWA KELAS XI DALAM MENULIS TEKS HORTATOTY EXPOSITION DI SMAN 14 PEKANBARU}

\begin{abstract}
Abstrak
Penelitian ini merupakan penelitian deskriptif untuk mendeskripsikan kemampuan siswa kelas XI di SMAN 14 Pekanbaru dalam menulis teks hortatory exposition. Jumlah siswa kelas XI di SMAN 14 Pekanbaru pada tahun ajaran 2015/2016 adalah 210 siswa yang terdiri dari 7 kelas. Dalam penelitian ini, peneliti menggunakan teknik cluster random sampling untuk memilih sampel, dan total sampel penelitian ini berjumlah 30 siswa. Data dikumpulkan melalui tes tulis, dimana siswa diminta untuk menulis teks hortatory exposition berdasarkan topik yang diberikan oleh peneliti dalam penelitian ini. Tes dilakukan sekitar 90 menit untuk setiap saat tes. Seluruh tes siswa dinilai oleh dua orang sebagai penilai pada penelitian ini. Kedua penilai tersebut memberikan nilai pada tes siswa berdasarkan kriteria dalam instrumentasi penelitian ini. Hasil penelitian menunjukkan bahwa kemampuan siswa dalam menulis teks hortatory exposition.
\end{abstract}


dikategorikan "average to good". Hal ini dapat dibuktikan dengan rata-rata nilai ujian tulis siswa yaitu 61.65 yang belum mencapai nilai KKM.

Kata kunci: Kemampuan Menulis, Teks Hortatory Exposition

\section{INTRODUCTION}

Writing is one of the four basic skills to be taught for the students. It is one way for the students to express their idea and opinion. Through writing the students can transfer their experiences and knowledge to other. So, they should be able to produce sentence and develop it into paragraph, essay, and paper. Brown (1994) says that "to make a good writing, a writer has to master the components of language; they are spelling, vocabulary, punctuation and grammar". That's why the students should pay attention to the diction used and should be able to arrange their ideas or feelings in good arrangement. In the other words, the students should determine the rhetorical structure of the text in writing.

Writing is the important skill that should be mastered by the students beside speaking, reading, and listening. As stated by Deporter (2000) and Zemach \& Rumisek (2005), writing is active thinking process of the students to plan, arrange, and express the ideas in order it can be understood by the reader. A good writing helps to avoid misunderstanding between the writer's ideas with the reader's opinion.

Moreover, the essence of writing, the writer should be able to make the readers comprehend about what he/she is talking about in written form. However, writing is not an easy activity because selection of word should be attended. The writer should also focus on whom their writing to be read. Those are the reasons why writing including in productive skill, which requires students' ability in producing a language to communicate.

In senior high school, writing skill should be learnt by the students. Based on English curriculum of senior high school, Kurikulum Tingkat Satuan Pendidikan (KTSP) in 2006, there are two types of text in teaching writing. They are functional text and monologue text. Functional text form can be announcement, advertisement, invitation, poster and pamphlet. While monologue can be informs of recount, narrative, report, spoof, procedure, explanation, analytical exposition, and hortatory exposition, discussion, and review texts.

According to the syllabus of senior high school at eleventh grade in English subject the students should master kinds of the text. They are report text, narrative text, spoof text, procedure text, explanation text, recount text, analytical exposition text and hortatory exposition text.

From the text above, hortatory exposition text is difficult enough to be learnt by the students. It is a text which gives the information that completed with the 
evidences, facts and statistics to support the idea of the text. It makes the students should work hard to provide the concrete data and more knowledge to convince his or her reader that the idea is important.

To have a good ability in writing hortatory exposition text, students must understand the generic structure and language feature of hortatory exposition. Gerot \& Wignell (1994) says that Generic structures consist of thesis, argument, and recommendation. Thesis is an announcement about the issues of concern. Next, Argument is containing of the reason of doing something. Simply, the students need to provide evidences, facts, and statistical data. Last, Recommendation is the statement of what ought to happen. Finally, language feature is important to be master because it makes the students writing in hortatory exposition text become easy to understand.

Based on the preliminary observation, which the researcher did on $15^{\text {th }}$ December 2015 , to the English teacher of SMAN 14 Pekanbaru and also asked some of the eleventh grade students of SMAN 14 Pekanbaru, it is found that the students have some problems in writing hortatory exposition text.

First, students' problems, they were not interested in thinking more, to, lack of vocabulary. Then, the students were reluctant to open their dictionary to find out the correct meaning and word, incorrect grammar, using punctuation, organize the sentence and explore the ideas. After that, they have problem to express about what they want to write. The problems above make the students produce a short and poor writing product. The second, teachers' problem in applying the strategy at the school already good, but the researcher found that the English teacher applied the similar strategy in teaching writing hortatory exposition.

Based on the problems above, the researcher wants to figure out students' ability of eleventh grade students at SMAN 14 Pekanbaru in writing hortatory exposition text.

\section{METHOD}

This research was a descriptive research. Its purpose is to describe the senior high school students' ability in writing hortatory exposition text. According to Gay (1987: 189), descriptive research involves collecting data in order to answer the question concerning the current status of the subject of the study. In addition, Amirul \& Haryono (2005: 151) say that this research shows and solves the actual and current problem and gathers the data to be arranged, explained, and analyzed. In order to get the data which are required to support this research, the writer employed the descriptive quantitative method.

This research was held in SMAN 14 Pekanbaru, at the second year students. It was located on Tengku Bey Street/Sei Mintan I. Simpang Tiga, Pekanbaru. Hence, this research was conducted on March up to April 2016.

The population of this research was the second year student of SMAN 14 Pekanbaru in the academic 
year 2015/2016. It consisted of seven classes and the number of students of each class was 30 students. The total numbers of the eleventh grade students of SMAN 14 Pekanbaru were 210 students.

In this research, the technique of sampling used by the researcher was cluster random sampling, because the whole students of the eleventh grade of senior high school were too many to be the participant for this research and each classes have different numbers of students which they have the same competency. According to Gay (2009) sample is the process of selecting a number of individuals for a study in such a way that individuals represent to larger group from which that were selected. In other words between XI IPA1 up to XI IPA 4 and XI IPS 1 up to XI IPS 3, there were none of them to be considered as an excellent class. Then, Gay (1987) defines that cluster random sampling is sampling in which groups not individuals were randomly selected. Between seven classes, the researcher choose one class as the sample by using lot with two rolls of small paper, which each roll contained of one class. These rolls of small paper were put into a bottle. Then the bottle was shaking and one of the papers was taken. The sample that had been chosen was XI IPA 1 that consisted of 30 students.

The research instrument for this research was writing paragraph test. The Instrument was used to find out the result of the students' writing ability. In analyzing the data, the writer used rubrics of writing adapted from Brown (2007). The rubric provide 5 component of writing namely, content, organization, Grammar, vocabulary, mechanics in which each of them was scaled from 1-4. To get the valid date, the researcher asked English teacher to analyze the students' writing.

In collecting the data for this research, the researcher distributed the sheet of written test of hortatory exposition text. There were some procedures that had been done. First, the researcher prepared topics. Students asked to choose one topic that they like to write. Second, the researcher gave the writing test and the students were given 90 minutes to do the test. Third, the researcher controls the test by herself. Finally, the researcher collected the students' writing to be analyzed.

After collecting the data, the researcher analyzed the result of the research. The researcher analyzed the data in several steps: first, the students writing were scored by the three scorers about content, organization, vocabulary, grammar, and mechanic. Second, after all of the students' text were scored, the students' score from all of the scorers in writing test added and divided by the researcher to get the average of the students' score in writing an analytical exposition text. To analyze it, the researcher use Sudijono formula (2011), the formula as follows:

$$
\mathrm{M}=\frac{\mathrm{Fx}}{\mathrm{n}} \mathrm{x} 100 \%
$$

Where :

$\mathrm{M}=$ the mean score

$\mathrm{Fx}=$ the total score

$\mathrm{n}=$ the number of students 
In addition, the students' score analyzed based on the passing grade which was 78 . It means that the mean score must be more than or equal 78.

After that, to interpret the data, the writer used the range of level ability as follows:

Table 1.3 Interpretation of the Students' Score in Term of the Level Ability

\begin{tabular}{|c|c|}
\hline SCORE & CATEGORIES \\
\hline $80-100$ & Good to Excelent \\
\hline $60-79$ & Average to Good \\
\hline $50-59$ & Poor to Average \\
\hline $0-49$ & Poor \\
\hline
\end{tabular}

\section{FINDING AND DISCUSSION}

The purpose of this research was to figure out the students' ability in writing hortatory exposition text at eleventh grade of SMAN 14 Pekanbaru. This study took at the second semester of eleventh grade as the sample. In this research, there were thirty (30) students followed the test.

In the test, the students were asked to write a hortatory exposition text based on the current topics that given by the researcher. In this research, the students' writing scored by two raters and the researcher of this research. The scorers gave score to the students' ability in writing analytical exposition text by using the criteria which are already explained in the instrumentation of the research.

In this research, the researcher analyzed the students' ability in writing a hortatory exposition text based on five writing components, which consist of; content, vocabulary, grammar, organization and mechanic. The students' scores were computed by combining scores from scorer 1 , scorer 2, and scorer 3 .

After administering the writing test to the students and calculating the result of writing score, it can be concluded that the second grade students' ability in writing hortatory exposition text categorized as "average to good". It can be proven by the mean score which was 61.65. Also, it means that most of eleventh grade students could not achieve the passing grade.

Also, the students' score can be seen from writing components. First, it can be seen from the content component, students got 484 points. Second is organization which the students got 280 point. Third, in Grammar, they got 318 points. Fourth, in Vocabulary, the students got 219 point. And the last is grammar which was 185 points.

In summary, from the result finding, the students' ability in writing hortatory exposition text was average to good. Also, most of students cannot achieve the passing grade which was 78 . It means that, this research with the title 'Students; Ability in Writing Hortatory Exposition Text at Eleventh Grade Students of SMAN 14 Pekanbaru" was found that the students still have problem in developing the idea, writing generic structure and language feature of hortatory exposition text, to achieve the passing grade, and writing a hortatory exposition text was hard to the 
students at the eleventh grade of Senior High school.

\section{CONCLUSION AND SUGGESTION}

\section{Conclusion}

This research focused on the students' ability in writing hortatory exposition text based on the five components writing which were content, vocabulary, grammar, organization, and mechanics at eleventh grade students of SMAN 14 Pekanbaru. After several processes of data analysis, the researcher concluded that the students' ability in writing analytical exposition text was average to good, where the average students' score was 61.65 and it cannot achieve the passing grade.

\section{Suggestion}

Based on the research finding, the researcher would like to promise some suggestions. First is for the teacher who teaches the eleventh grade students. The teacher is suggested to pay attention to five components of writing which are content, vocabulary, organization, grammar, and mechanic in teaching writing hortatory exposition text to the students. Besides that, the teacher should use various kinds of strategies and technique in teaching hortatory exposition text, and give many exercises to the students to improve the students' ability in comprehending hortatory exposition text and be able to write a good hortatory exposition text.
The second is for the students at the eleventh grade of senior high school who learn about hortatory exposition text. The students were suggested to learn and to do more exercise about generic structure and language feature in hortatory exposition text to have a good writing based on the five criteria.

The last is for the further researcher, the finding of this research is hoped can be sources and rubric in doing the next research which have relationship with research about writing hortatory exposition text itself.

\section{REFERENCES}

Amirul \& Haryono. (2005). Metodologi Penelitian Pendidikan. Bandung: CV Pustaka setia.

Brown, H. D. (2007). Principles of Language Learning and Teaching. San Francisco University: Pearson Longman.

Brown, H. Douglas. (1994). Principle of language Learning and Teaching. New Jersey: Prentice Hall Regents.

Depdiknas. (2006). Kurikulum Tingkat Satuan Pendidikan (KTSP). Jakarta: Departemen Pendidikan Nasional.

Deporter, B. (2000). Quantum Learning. Bandung: Kaifa.

Gay, L. R et al. (2009). Educational Research. New Jersey: Pearson Education. 
Gay, L. R. (1987). Educational Research. London: Merrill Publishing.

Gerot \& Wignell. (1994). Making Sense of Functional Grammar. Cammeray NSW: Antipodean Educational Enterprises.

Sudijono, Anas. (2011). Pengantar Statistik Pendidikan. Jakarta: Raja Grafindo Persada.

Zemach, D. E., \& Rumisek, L. A. (2005). Academic Writing: From Paragraph to Essay. Macmillan Publishers. 